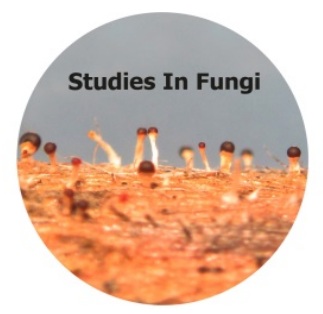

\title{
Bioactive potential of the wild edible mushroom Ramaria versatilis
}

\author{
Dattaraj HR ${ }^{1}$, Sridhar $\mathrm{KR}^{1,2}$, Jagadish $\mathrm{BR}^{1}$ and Pavithra $\mathbf{M}^{1}$ \\ ${ }^{1}$ Department of Biosciences, Mangalore University, Mangalagangotri, Mangalore, Karnataka, India \\ ${ }^{2}$ Centre for Environmental Studies, Yenepoya (deemed to be) University, Mangalore, Karnataka, India
}

Dattaraj HR, Sridhar KR, Jagadish BR, Pavithra M 2020 - Bioactive potential of the wild edible mushroom Ramaria versatilis. Studies in Fungi 5(1), 73-83, Doi 10.5943/sif/5/1/7

\begin{abstract}
The scrub jungles of the southwestern India support different mushrooms of economic significance. The coral mushrooms belong to the genus Ramaria distributed worldwide and many species are edible, medicinal and ectomycorrhizal. Ramaria versatilis occurring in scrub jungles were analyzed for biochemical profile and antioxidant potential. Qualitative tests of uncooked samples showed presence of saponins, flavonoids, alkaloids, terpenoids and coumarins, whereas the cooked samples possess saponins, alkaloids, terpenoids, cardiac glycosides and coumarins. Quantitative assessment revealed significantly higher quantities of total phenolics as well as vitamin $\mathrm{C}$ in uncooked than cooked samples. The total antioxidant activity, ferrous ion-chelation capacity and DPPH radical-scavenging activity were also significantly high in uncooked samples. Occurrence, substrates, mycorrhizal association and edibility of different Ramaria occurring in the Western Ghats region have been reviewed with comparison of nutritional and antioxidant potential of $R$. versatilis with other Ramaria spp.
\end{abstract}

Key words - Antioxidant activities - bioactive compounds - ectomycorrhizae - scrub jungles

\section{Introduction}

Cultivated as well as wild mushrooms meet the requirement of nutrition, medicine and bioactive compounds (Hobbs 1995, Smith et al. 2002, Boa 2004, Karun \& Sridhar 2017). More than 2,000 mushroom species worldwide have been regarded as safe for human consumption (Maihara et al. 2012). They have potential to serve as alternative to plant- and animal-derived nutritional as well as medicinal source. Edible mushrooms endowed with adequate quantities of proteins, fibre and essential amino acids with low amount of lipids (Sanmee et al. 2003, Kavishree et al. 2008, Pavithra et al. 2018). In addition to nutritional components, mushrooms provide many primary metabolites (e.g. oxalic acid and peptides) as well as secondary metabolites (e.g. steroids, terpenes and quinones) (Alves et al. 2012).

The Himalayas and Western Ghats are the major hotspots of mushroom diversity. The Western Ghats sustain edible, ectomycorrhizal and medicinal mushrooms (Farook et al. 2013, Karun \& Sridhar 2014, Senthilarasu 2014, Senthilarasu \& Kumaresan 2016). Similar to the Western Ghats, the scrub jungles, mangroves and coastal sand dunes of southwest India are also known for many economically valuable macrofungi (Sridhar 2018a). The diversity and distribution of macrofungi during southwest monsoon is the highest in Western Ghats region followed by scrub jungles, coastal sand dunes and mangroves (Sridhar 2018b).

Clavarioid mushrooms belong to the genus Ramaria is one of the diverse genera of the order Gomphales consisting 336 species (18 genera) worldwide with 616 names in Index Fungorum 
(Kirk et al. 2008, Giachini \& Castellano 2011). Under Nordic Ramaria project, Bendiksen et al. (2015) indentified 46 species of Ramaria based on morphological and molecular data. Over 20 Ramaria spp. grew in nutrient-poor coniferous forests. Among the clavarioid mushrooms, the Indian subcontinent offers 51 species of Ramaria with a highest record of 19 species in the State of Uttarakhand (Verma \& Pandro 2018).

Proximal components, minerals, fatty acids, amino acids and bioactive profile of traditionally edible 12 species of Ramaria occurring in Northwestern Himalayas have been evaluated by Sharma \& Gautam (2017). Edible Ramaria aurea consist of significant quantities of proteins, carbohydrates, amino acids, minerals and fibre as promising dietary supplement (Rai \& Acharya 2012). Another edible Ramaria botrytis consists of unsaturated fatty acids, tocopherol and other bioactive compounds (e.g. flavonoids, ascorbic acid, $\beta$-carotene and lycopene) (Barros et al. 2008). Edible Ramaria subalpina possesses significant antioxidant activity owing to presence of flavonoids, ascorbic acid, $\beta$-carotene and lycopene (Acharya et al. 2017). Ramaria spp. in Mexico consist of 53 edible and 40 ectomycorrhizal species, among them 16 species possess dual traits as edibility as well as ectomycorrhizal association (González-Ávila et al. 2013).

During expedition in scrub jungles of southwestern India, one of the edible mushrooms Ramaria versatilis was found on soil around the basins of many tree species including coconut (Cocos nucifera) trees with relative abundance 0.6-1.7\% (Greeshma et al. 2016, Dattaraj et al. 2020). Ramaria versatilis is also one of the ethnically edible wild mushrooms in Nepal, Western Himalayas (Christensen et al. 2008). This preliminary account records selected nutritional and bioactive components of uncooked and cooked $R$. versatilis occurring in the scrub jungles of South Western India in comparison with other Ramaria spp. as well as other edible wild mushrooms.

\section{Materials \& Methods}

\section{Mushrooms collection and treatments}

Ramaria versatilis Quél was frequent on the soil in scrub jungles in the basins of tree species during the southwest monsoon. The basidiomata have profuse dichotomous branching with lightbrown to dark-brown shades. Sufficient quantities of fruit bodies of $R$. versatilis from three locations by random sampling in the scrub jungles were collected in sterile polythene bags. They were rinsed in water to eliminate debris followed by blotting. Each replicate was grouped in to two parts, the first part served as uncooked sample (control), the second part was pressure-cooked with low quantity of water (similar to leafy vegetables). The samples were dried at $55 \pm 2^{\circ} \mathrm{C}$ in an hot-air oven until attaining constant weight. After drying, the samples were powdered by a hand grinder to get fine to coarse powder. The labeled samples were preserved in air-tight containers until further analysis.

\section{Qualitative tests}

Uncooked and cooked $5 \mathrm{~g}$ replicate samples of $R$. versatilis were extracted with $50 \mathrm{ml}$ distilled water in rotary shaker (150 rpm) (24 hr) (Banu \& Catherine 2015). After the extracts were centrifuged, supernatants were assessed for presence of bioactive components (phenols, tannins, phlobatannins, cardiac glycosides, saponins, terpenoids, coumarins, flavonoids and alkaloids) by following different methods (Trease \& Evans 1989, 2002, Safowora 1993, Herborne 1998, Parekh \& Chanda 2007, Das et al. 2010, Soares et al. 2013, Pandey \& Tripathi 2014).

Phenols - To $1 \mathrm{ml}$ extract, $2 \mathrm{ml}$ distilled water was added followed by addition of a few drops of $10 \%$ aqueous $\mathrm{FeCl}_{3}$. Formation of blue or green color reveals presence of phenols.

Tannins - To $2 \mathrm{ml}$ extract, $2 \mathrm{ml}$ distilled water and 2-3 drops of aqueous $1 \% \mathrm{FeCl}_{3}$ were added. Formation of brownish-green or green or blue-black color discloses presence of tannins.

Saponins - To $5 \mathrm{ml}$ extract, $5 \mathrm{ml}$ distilled water was added, heated, cooled to room temperature and shaken vigorously to develop foam. Formation of froth indicates occurrence of saponins. For emulsion test, to $5 \mathrm{ml}$ extract, $5 \mathrm{ml}$ distilled water was added, after vigorous shaking, 
the froth developed was mixed with 3 drops of olive oil and repeated shaking for the formation of emulsion as an indication of presence of saponins.

Flavonoids - To $2 \mathrm{ml}$ extract, $2 \mathrm{ml}$ methanol was added and heated, followed by addition of 2-3 drops of concentrated $\mathrm{HCl}$. Development of red or orange color is an evidence for presence of flavonoids.

Alkaloids - To $2 \mathrm{ml}$ extract was treated with $5 \mathrm{ml} 1 \% \mathrm{HCl}$, placed in steam bath for $10 \mathrm{~min}$ followed by filtering. $1 \mathrm{ml}$ filtrate was treated with 5-6 drops of Mayer's reagent (solution 1: 0.355 $\mathrm{g} \mathrm{HgCl}_{3}$ dissolved in $60 \mathrm{ml}$ distilled water; solution 2: $5 \mathrm{~g} \mathrm{KI}$ dissolved in $20 \mathrm{ml}$ distilled water; volume was made up to $100 \mathrm{ml}$ with distilled water after mixing solution 1 and 2). Formation of cream-colored precipitate shows presence of alkaloids.

Terpenoids - To $5 \mathrm{ml}$ extract was mixed with $2 \mathrm{ml}$ chloroform followed by addition of $1 \mathrm{ml}$ concentrated $\mathrm{H}_{2} \mathrm{SO}_{4}$ on the sides of the test tubes. Appearance of reddish-brown color in the interface shows presence of terpenoids.

Cardiac glycosides - To $5 \mathrm{ml}$ extract, $2 \mathrm{ml}$ mixture glacial acetic acid containing ferric chloride ( 1 volume of $5 \% \mathrm{FeCl}_{3}+99$ volume of glacial acetic acid) was added followed by $1 \mathrm{ml}$ concentrated $\mathrm{H}_{2} \mathrm{SO}_{4}$. Appearance of brown ring at the interface reveals positive test for cardiac glycosides.

Coumarins - To $2 \mathrm{ml}$ extract was treated with 2-3 $\mathrm{ml} 10 \%$ aqueous sodium hydroxide and formation of yellow color indicates presence of coumarins.

Phlobatannins - To $2 \mathrm{ml}$ extract was boiled with $2 \mathrm{ml} 1 \% \mathrm{HCl}$ for formation of red precipitate as positive for presence of phlobatannins.

\section{Quantitative tests}

Total phenolics - Total phenolic content of uncooked and cooked mushroom was assessed according to Rosset et al. (1982). $50 \mathrm{mg}$ samples was extracted with $5 \mathrm{ml}$ of $50 \%$ aqueous methanol and $5 \mathrm{ml}$ distilled water in water bath $\left(95 \pm 1^{\circ} \mathrm{C}\right)$ for $10 \mathrm{~min}$, centrifuged at $1500 \mathrm{rpm}$ and the supernatant was drawn. The leftover material was re-extracted, pooled extracts and made up to 10 $\mathrm{ml}$ with distilled water. Aliquots of $0.1 \mathrm{ml}$ were made up to $1 \mathrm{ml}$ by distilled water followed by addition of $5 \mathrm{ml} 2 \% \mathrm{Na}_{2} \mathrm{CO}_{3}$ (in $0.1 \mathrm{~N} \mathrm{NaOH}$ ). After incubation up to $10 \mathrm{~min}$ at room temperature, $0.5 \mathrm{ml}$ Folin-Ciocalteu's reagent $(1: 2 \mathrm{v} / \mathrm{v})$ was added, mixed and absorbance value was measured at $725 \mathrm{~nm}$. Tannic acid served as standard and the results expressed as mg tannic acid equivalents (TAEs) per gram mushroom dry mass (mg TAEs/g).

Vitamin C - Vitamin C content of mushroom samples was estimated as per the method by Roe (1954) with a slight modification. Five gram mushroom samples were extracted with $25 \mathrm{ml}$ of trichloroacetic acid (TCA) (5\%). Aliquots of $0.5 \mathrm{ml}$ of samples were made up to $1 \mathrm{ml}$ using $5 \%$ TCA followed by addition of $1 \mathrm{ml}$ chromogen reagent ( $0.6 \%$ copper sulfate, $5 \mathrm{ml}+5 \%$ Thiourea, 5 $\mathrm{ml}+2.2 \%$ 2,4-dinitrophenylehydrazine, $90 \mathrm{ml}$ ). After boiling the mixture (10 min), cooled to room temperature, $4 \mathrm{ml}$ of $65 \% \mathrm{H}_{2} \mathrm{SO}_{4}$ was added and incubated up to $30 \mathrm{~min}$ at room temperature. Using ascorbic acid as standard, the absorbance value was measured at $540 \mathrm{~nm}$ and vitamin $\mathrm{C}$ content was expressed in mg ascorbic acid equivalents (AAEs) per gram mushroom dry mass (mg AAEs/g).

\section{Antioxidant tests}

Total antioxidant activity - Total antioxidant activity (TAA) of mushroom flour was evaluated according to Prieto et al. (1999) with a few modifications. Aqueous $0.2 \mathrm{ml}$ mushroom extracts were treated with $2 \mathrm{ml}$ reagent mixture $\left(\mathrm{H}_{2} \mathrm{SO}_{4}, 0.6 \mathrm{M}+\right.$ sodium phosphate, $28 \mathrm{mM}+$ ammonium molybdate, $4 \mathrm{mM}$ ). After incubation of mixtures at $95^{\circ} \mathrm{C}$ for $90 \mathrm{~min}$, cooled to room temperature and absorbance value was measured at $695 \mathrm{~nm}$ against distilled water as blank. The TAA was expressed as $\mu \mathrm{M}$ equivalent of ascorbic acid equivalents per gram mushroom flour $(\mu \mathrm{M}$ AAEs/g).

Ferrous ion-chelation capacity - Ferrous ion-chelating capacity (FCC) was assessed based on Hsu et al. (2003). One ml aqueous extracts were treated with $0.1 \mathrm{ml} 2 \mathrm{mM} \mathrm{FeCl}_{3}$ and $0.2 \mathrm{ml} 5$ 
$\mathrm{mM}$ ferrozine. The volume was made up to $5 \mathrm{ml}$ with distilled water. The absorbance was measured at $562 \mathrm{~nm}$ after incubation of mixture for $10 \mathrm{~min}$ at room temperature. The reagents devoid of sample served as control.

Ferrous ion-chelating capacity $(\%)=\left[1-\left(A s_{562} / A c_{562}\right)\right] \times 100$ (where Ac, absorbance of control; As, absorbance of sample).

$D P P H$ radical-scavenging activity - The aqueous extracts were assessed for radicalscavenging activity by following Singh et al. (2002). Different concentrations of extract (0.2-1.0 mg) were made up to $1 \mathrm{ml}$ with distilled water. $4 \mathrm{ml} 0.01 \mathrm{mM}$ 2,2-diphenyl-1-picrylhydrazyl (DPPH) was added followed by incubation at room temperature up to $20 \mathrm{~min}$. The absorbance value was measured at $517 \mathrm{~nm}$ and reagents without sample served as control.

Free radical-scavenging activity $(\%)=\left[\left(A c_{517}-A s_{517}\right) /\left(A c_{517}\right)\right] \times 100(\mathrm{Ac}$, absorbance of the control; As, absorbance of the sample).

\section{Data analysis}

The significant difference in total phenolics, vitamin $\mathrm{C}$ and antioxidant activities among uncooked and cooked samples of $R$. versatilis was determined by $t$-test (StatSoft 2008).

\section{Results \& Discussion}

\section{Ramaria in the Western Ghats}

The literature survey reveals that 10 species of Ramaria are known from the Western Ghats region (Table 1). Reports on Ramaria spp. are available from the states of Maharashtra (3 spp.), Karnataka (7 spp.) and Kerala (7 spp.). All these Ramaria spp. except for $R$. eumorpha have been listed to have mutualistic association (ectomycorrhizal) with several tree species in Mexico and other parts of the world (González-Ávila et al. 2013). Except R. eumorpha and R. zippelii, the rest of the species are edible in Mexico. Although diverse Ramaria spp. have been assessed for their morphology, phylogeny and bioactive components in the Western Ghats, their nutritional and mutualistic association have not been assessed.

Table 1 Ramaria spp. reported from the Western Ghats region (?, to be defined; *, González-Ávila et al. 2013).

\begin{tabular}{|c|c|c|c|c|c|}
\hline & Common name & Location & $\begin{array}{l}\text { Substrate } \\
\text { (Reference) }\end{array}$ & Mutualism* & Edibility* \\
\hline $\begin{array}{l}\text { Ramaria } \\
\text { apiculata } \\
\text { (Fr.) Donk }\end{array}$ & $\begin{array}{l}\text { Green-tipped } \\
\text { coral mushroom }\end{array}$ & $\begin{array}{l}\text { Radhanagari } \\
\text { (Maharashtra) } \\
\text { Ammayambalam } \\
\text { (Kerala) }\end{array}$ & $\begin{array}{l}\text { Soil (Thite et al. } \\
\text { 1976, Patil \& Thite } \\
\text { 1977) } \\
\text { Soil \& humus } \\
\text { (Mohanan 2011) }\end{array}$ & Mycorrhizal & Edible \\
\hline $\begin{array}{l}\text { Ramaria } \\
\text { botrytis } \\
\text { (Pers.) } \\
\text { Bourdot }\end{array}$ & $\begin{array}{l}\text { Pink-tipped } \\
\text { coral or } \\
\text { Cauliflower } \\
\text { mushroom }\end{array}$ & $\begin{array}{l}\text { Panhala } \\
\text { (Maharashtra) } \\
\text { Shimoga } \\
\text { (Karnataka) }\end{array}$ & $\begin{array}{l}\text { Humus-rich soil } \\
\text { (Patil et al. 2016-17) } \\
\text { Soil (Swapna et al. } \\
\text { 2008) }\end{array}$ & Mycorrhizal & Edible \\
\hline $\begin{array}{l}\text { Ramaria } \\
\text { eumorpha (P. } \\
\text { Karst.) } \\
\text { Corner }\end{array}$ & $\begin{array}{l}\text { Rose-bud } \\
\text { mushroom }\end{array}$ & $\begin{array}{l}\text { Chandhakkunnu } \\
\text { (Kerala) }\end{array}$ & $\begin{array}{l}\text { Soil \& humus } \\
\text { (Mohanan 2011) }\end{array}$ & ? & ? \\
\hline $\begin{array}{l}\text { Ramaria } \\
\text { flava } \\
\text { (Schaeff.) } \\
\text { Quél. }\end{array}$ & $\begin{array}{l}\text { Yellow coral } \\
\text { mushroom }\end{array}$ & $\begin{array}{l}\text { Soil (Karnataka) } \\
\text { Chandhakkunnu } \\
\text { (Kerala) }\end{array}$ & $\begin{array}{l}\text { Soil (Karun \& } \\
\text { Sridhar 2016) } \\
\text { Soil \& humus } \\
\text { (Mohanan 2011) }\end{array}$ & Mycorrhizal & Edible \\
\hline $\begin{array}{l}\text { Ramaria } \\
\text { formosa } \\
\text { (Pers.) Quél. }\end{array}$ & $\begin{array}{l}\text { Yellow-tipped } \\
\text { coral mushroom }\end{array}$ & $\begin{array}{l}\text { Dandeli } \\
\text { (Karnataka) } \\
\text { Chandhakkunnu } \\
\text { (Kerala) }\end{array}$ & $\begin{array}{l}\text { Soil (Ramesh \& } \\
\text { Pattar 2010) } \\
\text { Soil \& humus } \\
\text { (Mohanan 2011) }\end{array}$ & Mycorrhizal & Edible \\
\hline
\end{tabular}


Table 1 Continued.

\begin{tabular}{|c|c|c|c|c|c|}
\hline & Common name & Location & $\begin{array}{l}\text { Substrate } \\
\text { (Reference) }\end{array}$ & Mutualism* & Edibility* \\
\hline $\begin{array}{l}\text { Ramaria } \\
\text { gracilis } \\
\text { (Pers.) Quél. }\end{array}$ & $\begin{array}{l}\text { Coral } \\
\text { mushroom }\end{array}$ & $\begin{array}{l}\text { Soil (Karnataka) } \\
\text { Peechi (Kerala) }\end{array}$ & $\begin{array}{l}\text { Soil (Karun \& } \\
\text { Sridhar 2016) } \\
\text { Soil \& humus } \\
\text { (Mohanan 2011) }\end{array}$ & Mycorrhizal & Edible \\
\hline $\begin{array}{l}\text { Ramaria } \\
\text { pallida } \\
\text { (Schaeff.) } \\
\text { Ricken }\end{array}$ & $\begin{array}{l}\text { Colic coral } \\
\text { mushroom }\end{array}$ & $\begin{array}{l}\text { Sidhanpocket } \\
\text { (Kerala) }\end{array}$ & $\begin{array}{l}\text { Soil (Karun \& } \\
\text { Sridhar 2014, } \\
\text { Pavithra et al. 2016a, } \\
\text { Dattaraj et al. 2020) } \\
\text { Humus-rich soil } \\
\text { (Mohanan 2011) }\end{array}$ & Mycorrhizal & Edible \\
\hline $\begin{array}{l}\text { Ramaria } \\
\text { stricta (Pers.) } \\
\text { Quél. }\end{array}$ & $\begin{array}{l}\text { Strict-branch } \\
\text { coral mushroom }\end{array}$ & $\begin{array}{l}\text { Koodlu Theertha } \\
\text { (Karnataka) }\end{array}$ & $\begin{array}{l}\text { Soil (Prakash \& } \\
\text { Colney 2019) }\end{array}$ & Mycorrhizal & Edible \\
\hline $\begin{array}{l}\text { Ramaria } \\
\text { versatilis } \\
\text { Quél. }\end{array}$ & ? & $\begin{array}{l}\text { Konaje } \\
\text { (Karnataka) } \\
\text { Chandhakkunnu } \\
\text { (Kerala) }\end{array}$ & $\begin{array}{l}\text { Soil (Greeshma et al. } \\
\text { 2016, Dattaraj et al. } \\
\text { 2020) } \\
\text { Soil \& humus } \\
\text { (Mohanan 2011) }\end{array}$ & Mycorrhizal & Edible \\
\hline $\begin{array}{l}\text { Ramaria } \\
\text { zippelii (Lév.) } \\
\text { Corner }\end{array}$ & ? & $\begin{array}{l}\text { Mahabaleshwar } \\
\text { (Maharashtra) }\end{array}$ & $\begin{array}{l}\text { Soil (Senthilarasu } \\
\text { 2013) }\end{array}$ & Mycorrhizal & ? \\
\hline
\end{tabular}

\section{Bioactive components}

Qualitative tests of uncooked samples revealed occurrence of saponins, flavonoids, alkaloids, terpenoids and coumarins, whereas cooked samples consist of saponins, alkaloids, terpenoids, cardiac glycosides and coumarins. However, both samples devoid of phenols, tannins and phlobatannins. As saponins, flavonoids, alkaloids and terpenoids are known for antibacterial activity (Machumi et al. 2010, Aboh et al. 2014), probably these compounds may defend the mushrooms against bacterial attack in their habitats. Many edible Ramaria spp. (R. aurea, $R$. botrytis, $R$. cystidiophora, $R$. flava, $R$. flavescens, $R$. formosa, $R$. rubripermanens and $R$. stricta) are known for antimicrobial potential against pathogens (bacteria, mycobacteria and fungi) (Barros et al. 2008, Ramesh \& Pattar 2010, Centko et al. 2012, Sharma \& Gautam 2017). Besides, these compounds are also possessing antioxidant potential (Poumale et al. 2013, Nithya et al. 2016). The cardiac glycosides (or aglycones) are known to raise the capability of blood pumping by heart muscle (Aldred 2008). The coumarins have many bioactive potential (e.g. antioxidant, antimicrobial, antiinflammatory and antidiabetic) (Poumale et al. 2013). The qualitative assessment of $R$. versatilis revealed occurrence of typical bioactive components presented in medicinal plant species, thus serve as potential alternative therapeutic source. Thermal and other processing methods may influence the quantity as well as loss of some bioactive components of edible mushrooms, whereas some compounds those are not present in raw mushrooms may perceive after processing. However, some bioactive components may be below detectable level by qualitative or quantitative analysis.

Quantitative tests for total phenolics and vitamin C showed worthy result. The total phenolics was significantly higher in uncooked than cooked samples $(\mathrm{p}<0.05)$ (Fig. 1a). The total phenolics in uncooked as well as cooked $R$. versatilis is higher than other edible mushrooms of scrub jungles (e.g. Astraeus hygrometricus, Amanita sp. and Auricularia auricula) (Karun et al. 2016, Pavithra et al. 2016b, Greeshma et al. 2018). The total phenolics content of uncooked samples is comparable to uncooked Lentinus squarrosulus, Termitomyces clypeatus and T. umkowaan (Karun et al. 2016, Ghate \& Sridhar 2017). The total phenolics content not decreased drastically in $R$. versatilis on cooking as in L. squarrosulus, T. clypeatus and T. umkowaan. Conventional pressure-cooking 
employed in the present study will not destroy total phenolics, thus cooked $R$. versatilis have potential to quench the free radicals.

The vitamin $C$ content was significantly higher in uncooked than cooked samples $(p<0.05)$ (Fig. 1b). Vitamin C is one of the common constituents in many Ramaria spp., and its content in uncooked and cooked $R$. versatilis in our study are higher than eight Ramaria spp. studied by previous researches (Barros et al. 2008, Ramesh \& Pattar 2010, Acharya et al. 2017, Sharma \& Gautam 2017). Similarly, the vitamin $C$ content in $R$. versatilis is higher than many uncooked and cooked edible mushrooms occurring the scrub jungles (A. hygrometricus, A. auricula and L. squarrosulus and T. umkowaan) (Karun et al. 2016, Pavithra et al. 2016b, Ghate \& Sridhar 2017). However, vitamin $\mathrm{C}$ content is comparable with T. clypeatus, while lower than Amanita sp. occurring in scrub jungles (Ghate \& Sridhar 2017, Greeshma et al. 2018).
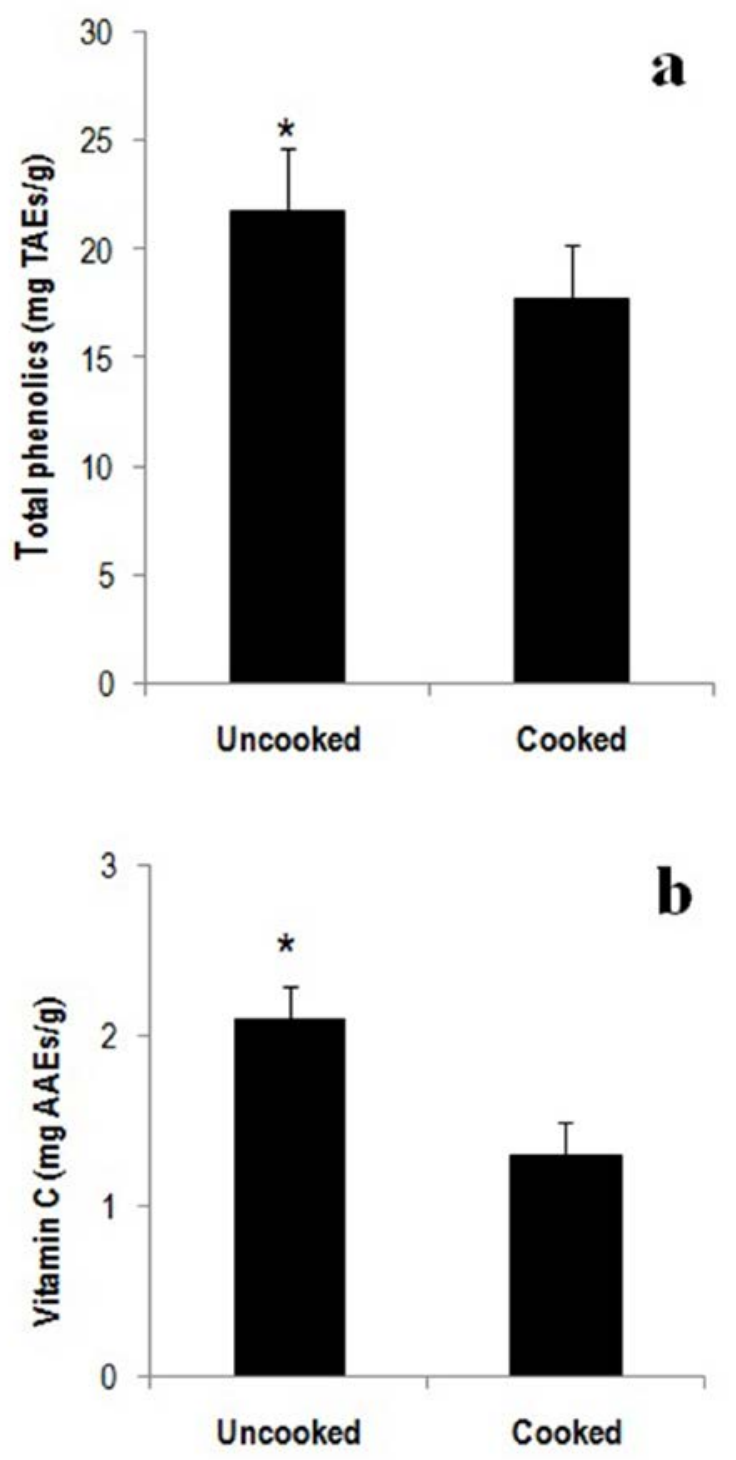

Fig. 1 - Total phenolics (a) and vitamin C (b) in uncooked and cooked Ramaria versatilis; mean $\pm S D$, $n=3$; $t$-test: $\left.{ }^{*} \mathrm{p}<0.05\right)$.

\section{Antioxidant potential}

The TAA of Ramaria versatilis was significantly higher in uncooked than cooked samples $(p<0.05)$ (Fig. 2a). The FCC was also significantly high in uncooked samples $(p<0.01)$ (Fig. $2 b)$. Similar to TAA and FCC, the DPPH radical-scavenging activity was higher in uncooked than cooked samples, it was significant at $0.2,0.8$ and $1 \mathrm{mg} / \mathrm{ml}(\mathrm{p}<0.05)$ (Fig. $2 \mathrm{c})$. In all the three tests, 
uncooked samples possess better antioxidant potential than cooked samples. The TAA of $R$. versatilis was comparable with other edible mushrooms in scrub jungles (Amanita sp., A. hygrometricus, T. clypeatus and T. umkowaan), while lower than A. auricula (Karun et al. 2016, Pavithra et al. 2016b, Ghate \& Sridhar 2017, Greeshma et al. 2018). The FCC is higher than Amanita sp. and A. auricula, while comparable to A. hygrometricus, L. squarrosulus, T. umkowaan, but lower than T. clypeatus. The DPPH radical-scavenging activity is lower than Amanita sp. and A. hygrometricus, while it is higher than A. auricula, T. umkowaan, L. squarrosulus and T. clypeatus. Ramaia subalpina also possess good antioxidant activity similar to $R$. versatilis (Acharya et al. 2017). Ramaria formosa possess lower DPPH radical-scavenging activity than $R$. versatilis (Ramash \& Pattar 2010). Among the six Ramaria spp. evaluated by Sharma \& Gautam (2017), the DPPH radical-scavenging activity of $R$. versatilis is comparable with three Ramaria spp. ( $R$. botrytis, $R$. flava and $R$. rubripermanes), while lower than other three Ramaria spp. (R. aurea, $R$. Flavescens and R. stricta).
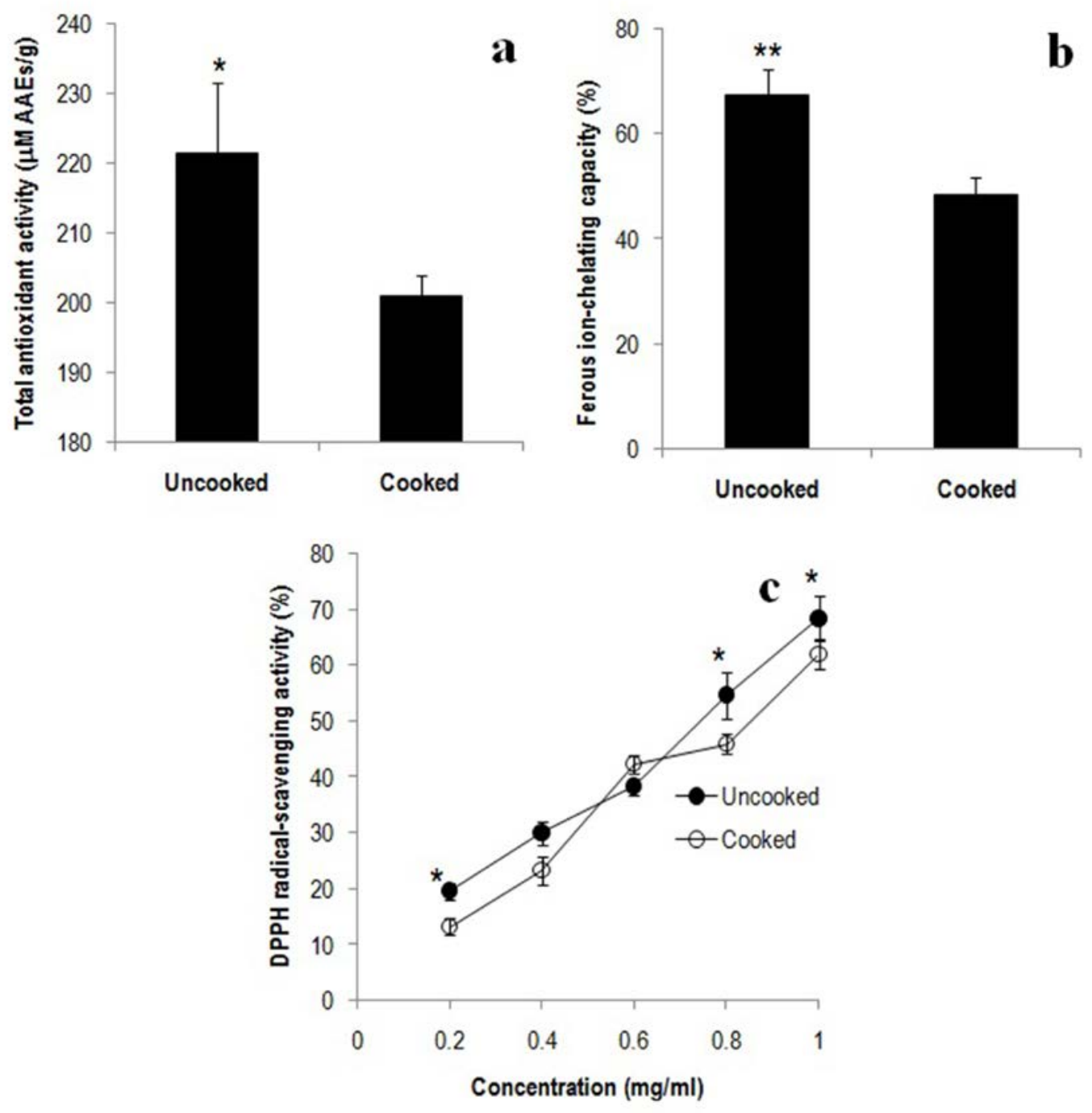

Fig. 2 - Total antioxidant activity (a), ferrous ion-chelating capacity (b) and DPPH radicalscavenging activity (c) of uncooked and cooked Ramaria versatilis (mean $\pm \mathrm{SD}, \mathrm{n}=3$; $t$-test: $\left.{ }^{*} \mathrm{p}<0.05,{ }^{* *} \mathrm{p}<0.01\right)$.

\section{Conclusions}

Aqueous extract of uncooked and cooked wild edible mushroom Ramaria versatilis occurring in the scrub jungles of the southwest India contains many bioactive components similar to plant 
species. The total antioxidant, ferrous ion-chelation and DPPH radical-scavenging activities are comparable or higher than many edible wild mushrooms occurring in the scrub jungles as well as other Ramaria spp. In the scrub jungles, $R$. versatilis grows in the basins of tree species including the basins of coconut (Cocos nucifera). Coconut being one of the important plantation crops of southwestern India, it is likely that $R$. versatilis has ectomycorrhizal association. Further precise studies on nutritional components, bioactive potential and ectomycorrhizal association of $R$. versatilis in the scrub jungles will be highly rewarding.

\section{Acknowledgements}

Authors are thankful to the Department of Biosciences, Mangalore University for facilities to carry out this study. We are indebted to the referees for constructive suggestions to improve the presentation of this paper.

\section{References}

Aboh MI, Olayinka BO, Adeshina GO, Oladosu P. 2014 - Antifungal activities of phyto compounds from Mitracarpus villosus (Sw.) DC from Abuja, Nigeria. Journal of Microbiological Research 4, 86-91.

Acharya K, Das K, Paloi S, Dutta AK et al. 2017 - Exploring a novel edible mushroom Ramaria subslpina: Chemical characterization and antioxidant activity. Pharmacognosy Journal 9, 30-34.

Aldred EM. 2008 - Pharmacology: A handbook for complementary healthcare professionals, 1st Edition. Churchill Livingstone, Elsevier Health services, UK.

Alves MJ, Ferreira ICFR, Dias J, Martins A, Pintado M. 2012 - A review on antimicrobial activity of mushroom (Basidiomycetes) extracts and isolated compounds. Planta Medica 78, 17071718.

Banu KS, Catherine L. 2015 - General technique involved in phytochemical analysis. International Journal of Advanced Research in Chemical Science 2, 25-32.

Barros L, Venturini BA, Baptista P, Estevinho LM, Ferreira IC. 2008 - Chemical composition and biological properties of Portuguese wild mushrooms: A comprehensive study. Journal of Agricultural and Food Chemistry 56, 3856-3862.

Bendiksen K, Kytövuori I, Toivonen M, Bendiksen E, Brandrud E. 2015 - Ectomycorrhizal Ramaria species in nutrientpoor Fennoscandian conifer forests including a note on the Ramaria botrytis complex. Agarica 36, 89-108.

Boa E. 2004 - Wild edible fungi, a global overview of their use and importance to people. NonWood Forest Products Series \#17, FAO, Rome.

Centko RM, Ramón-Garcia S, Taylor T, Patrick O et al. 2012 - Ramariolides A-D, Antimycobacterial Butenolides Isolated from the Mushroom Ramaria cystidiophora. Journal of Natural Products 75, 2178-2182.

Christensen M, Bhattarai S, Devkota S, Larsen HO. 2008 - Collection and Use of Wild Edible Fungi in Nepal. Economic Botany 62, 12-23.

Das K, Tiwari RKS, Shrivastava DK. 2010 - Techniques for evaluation of medicinal plant products as antimicrobial agent: Current methods and future trends. Journal of Medicinal Plants Research 4, 104-111.

Dattaraj HR, Sridhar KR, Jagadish BR. 2020 - Diversity and bioprospect significance of macrofungi in the scrub jungles of southwest India. In: Biodiversity and biomedicine, Egamberdieva D, Pešić M, Öztürk M (eds), Elsevier (in press).

Farook VA, Khan SS, Manimohan P. 2013 - A checklist of agarics (gilled mushrooms) of Kerala State, India. Mycosphere 4, 97-131. 
Ghate SD, Sridhar KR. 2017 - Bioactive potential of Lentinus squarrosulus and Termitomyces clypeatus from the southwestern region of India. Indian Journal of Natural Products and Resources 8, 120-131.

Giachini A, Castellano M. 2011 - A new taxonomic classification for species in Gomphus sensu lato. Mycotaxon 115, 183-201.

González-Ávila PA, Luna-Vega I, Rios MV, Lira R, Cifuentes J. 2013 - Current knowledge and importance of the order Gomphales (Fungi: Basidiomycota) in Mexico. Nova Hedwigia 97, 55-86.

Greeshma AA, Sridhar KR, Pavithra M, Ghate SD. 2016 - Impact of fire on the macrofungal diversity of scrub jungles of Southwest India. Mycology 7, 15-28.

Greeshma AA, Sridhar KR, Pavithra M, Tomita-Yokotani K. 2018 - Bioactive potential of nonconventional edible wild mushroom Amanita. In: Fungi and their role in sustainable development: Current perspectives. Gehlot P, Singh J (eds), Springer Nature, Singapore, pp. 719-738.

Herborne JB. 1998 - Phytochemical methods, 3rd Edition. Chapman \& Hall, London.

Hobbs C. 1995 - Medicinal mushrooms: An exploration of tradition healing \& culture. Botanica Press, California.

Hsu CL, Chen W, Weng YM, Tseng CY. 2003 - Chemical composition, physical properties and antioxidant activities of yam flours as affected by different drying methods. Food Chemistry 83, 85-92

Karun NC, Sridhar KR, Niveditha VR, Ghate SD. 2016 - Bioactive potential of two wild edible mushrooms of the Western Ghats of India. In: Fruits, vegetables, and herbs: bioactive foods in health promotion. Watson RR, Preedy VR (eds), Elsevier Inc., Oxford, UK, pp. 344-362.

Karun NC, Sridhar KR. 2014 - A preliminary study on macrofungal diversity in an arboretum and three plantations of the southwest coast of India. Current Research in Environmental and Applied Mycology 4, 173-187.

Karun NC, Sridhar KR. 2016 - Spatial and temporal diversity of macrofungi in the Western Ghat forests of India. Applied Ecology Environmental Research 14, 1-21.

Karun NC, Sridhar KR. 2017 - Edible wild mushrooms in the Western Ghats: Data on the ethnic knowledge. Data in Brief 14, 320-328.

Kavishree S, Hemavathy J, Lokesh BR, Shashirekha MN, Rajarathnam S. 2008 - Fat and fatty acids of Indian edible mushrooms. Food Chemistry 106, 597-602.

Kirk P, Cannon P, Winter D, Stalper J. 2008 - Dictionary of the fungi, 10th Edition. CAB International, Wallingford.

Machumi F, Samoylenko V, Yenesew A, Derese S. et al. 2010 - Antimicrobial and antiparasitic abietane diterpenoids from the roots of Clerodendrum eriophyllum. Natural Product Communications 5, 853-858.

Maihara VA, Moura PLDC, Catharino MGM, Moreira EG et al. 2012 - Cadmium determination in Lentinus edodes mushroom species. Food Science and Technology 32, 553-557.

Mohanan C. 2011 - Macrofungi of Kerala. Handbook \# 27. Kerala Forest Research Institute, Peechi, Kerala, India.

Nithya TG, Jayanthi J, Raghunathan MG. 2016 - Antioxidant activity, total phenol, flavonoid, alkaloid, tannin, and saponin contents of leaf extracts of Salvinia molesta d.s. mitchell (1972). Asian Journal of Pharmaceutical and Clinical Research 9, 200-203.

Pandey A, Tripathi S. 2014 - Concept of standardization, extraction and pre phytochemical screening strategies for herbal drug. Journal of Pharmacognosy and Phytochemistry 2, 115119.

Parekh J, Chanda S. 2007 - Antibacterial and phytochemical studies on twelve species of Indian medicinal plants. African Journal of Biomedical Research 10, 175-181. 
Patil CR, Bhise MR, Patil JC, Patil SC. 2016-17 - Addition of macrofungi to fungi of India from Kolhapur District. Journal of Shivaji University (Science \& Technology) 42, 10-16.

Patil MS, Thite AN. 1977 - Some fleshy fungi from Maharashtra - III. Indian Phytopathology 31, 32-35.

Pavithra M, Sridhar KR, Greeshma AA, Karun NC. 2016a - Spatial and temporal heterogeneity of macrofungi in the protected forests of Southwestern India. Journal of Agricultural Technology 12, 105-124.

Pavithra M, Sridhar KR, Greeshma AA, Tomita-Yokotani K. 2016b - Bioactive potential of the wild mushroom Astraeus hygrometricus in the southwest India. Mycology 7, 191-202.

Pavithra M, Sridhar KR, Greeshma AA. 2018 - Nutritional quality attributes of edible gasteroid wild mushroom Astraeus hygrometricus. In: Fungi and their role in sustainable development: Current perspectives. Gehlot P, Singh J (eds), Springer Nature, Singapore, pp. 367-382.

Poumale HMP, Hamm R, Zang Y, Shiono Y, Kuete V. 2013 - Coumarins and related compounds from the medicinal plants of Africa. In: Medicinal plant research in Africa, 1st Edition. Kuete V (ed), pp. 261-300.

Prakash PY, Colney Z. 2019 - Macrofungal biodiversity in the Western Ghat foot hill semi-urban city of Manipal and forest terrains of Koodlu Theertha falls, Karnataka. Current Research in Environmental \& Applied Mycology 9, 321-326.

Prieto P, Pineda M, Aguilar M. 1999 - Spectrophotometric quantitation of antioxidant capacity through the formation of a phosphomolybdenum complex: Specific application to the determination of vitamin E. Analytical Biochemistry 269, 337-341.

Rai M, Acharya K. 2012 - Proximate composition, free radical scavenging and NOS activation properties of Ramaria aurea. Research Journal of Pharmaceutical Technology 5, 1421-1427.

Ramesh Ch, Pattar MG. 2010 - Antimicrobial properties, antioxidant activity and bioactive compounds from six wild edible mushrooms of Western Ghats of Karnataka, India. Pharmacognosy Research 2, 107-112.

Roe JH. 1954 - Chemical determination of ascorbic, dehydroascorbic and diketogluconic acids. In: Methods of biochemical analysis, Volume 1. Glick D (ed), InterScience Publishers, New York, pp. 115-139.

Rosset J, Bärlocher F, Oertli JJ. 1982 - Decomposition of conifer needles and deciduous leaves in two black Forest and two Swiss Jura streams. International Review der Gesamten Hydrobiologie 67, 695-711.

Safowora A. 1993 - Medicinal plants and traditional medicine in Africa. John Wiley and Sons Limited, pp. 96-106.

Sanmee R, Dell B, Lumyong P, Izumori K, Lumyong S. 2003 - Nutritive value of popular wild edible mushrooms from northern Thailand. Food Chemistry 82, 527-532.

Senthilarasu G. 2013 - A checklist of Ramaria of India and an interesting blue species from Western Ghats. KAVAKA 41, 6-10.

Senthilarasu G. 2014 - Diversity of agarics (gilled mushrooms) of Maharashtra, India. Current Research in Environmental \& Applied Mycology 4, 58-78.

Senthilarasu G, Kumaresan V. 2016 - Diversity of agaric mycota of Western Ghats of Karnataka, India. Current Research in Environmental and Applied Mycology 6, 75-101.

Sharma SK, Gautam N. 2017 - Chemical and bioactive profiling, and biological activities of coral fungi from Northwestern Himalayas. Scientific Reports, 7, 46570.

Singh RP, Murthy CKN, Jayaprakasha GK. 2002 - Studies on antioxidant activity of pomegranate (Punica granatum) peel and seed extracts using in vitro methods. Journal of Agricultural and Food Chemistry 50, 81-86.

Smith JE, Rowan N, Sullivan R. 2002 - Medicinal mushrooms: Their therapeutic properties and current medical usage with special emphasis on cancer treatments. Cancer Research, London.

Soares MO, Alves RC, Pires PC, Oliveira MB, Vinha AF. 2013 - Angolan Cymbopogon citratus used for therapeutic benefits: Nutritional composition and influence of solvents in 
phytochemicals content and antioxidant activity of leaf extracts. Food and Chemical Toxicology 60, 413-418.

Sridhar KR. 2018a - Highlights on the macrofungi of southwest coast of Karnataka, India. International Journal of Life Sciences A9, 37-42.

Sridhar KR. 2018b - Diversity of macrofungi of Mangalore University Campus. In: Biodiversity of Mangalore University campus. Mangalore University, Mangalore, India, pp. 159-164.

StatSoft. 2008 - Statistica, Version 8. StatSoft Inc., Oklahoma, USA.

Swapna S, Abrar S, Krishnappa M. 2008 - Diversity of macrofungi in semi-evergreen and moist deciduous forest of Shimoga District, Karnataka, India. Journal of Mycology and Plant Pathology 38, 21-26.

Thite AN, Patil MS, More TN. 1976 - Some fleshy fungi from Maharashtra. Botanique 7, 77-78.

Trease GE, Evans WC. 1989 - Pharmacognosy, 11th Edition. Bailliere Tindall, London.

Trease GE, Evans WC. 2002 - Pharmacognosy, 15th Edition. Saunders Publishers, London.

Verma RK, Pandro V. 2018 - Diversity and distribution of clavarioid fungi in India, three fungi from Central India. International Journal of Current Microbiology and Applied Science 7, 2129-2147. 